\title{
A CENTRAL TÉRMICA DOS HUC (EDIFÍCIO DAS CALDEIRAS): MONUMENTO INDUSTRIAL A PRESERVAR E REUTILIZAR
}

\section{NT ROD UÇ Ã O}

À luz de uma noção tradicional (embora ainda muito em voga) de património cultural, praticamente só os monumentos de tipo clássico são «dignos» de consideração e, bem assim, objecto de estudo e salvaguarda. Porém, a dita noção tem vindo a sofrer alterações, designadamente ao adquirir um sentido mais lato. Assim, o património cultural tem passado a integrar outros vectores da realidade, até há pouco reputados de pouco ou nenhum significado cultural. Consequentemente, também o conceito de «monumento» tem vindo a alargar o seu âmbito, o que permite aplicá-lo a objectos de vária índole, entre os quais os de épocas mais recentes, bem como os relativos ao quotidiano ('). Como é sabido, estes constituem, afinal, testemunhos da chamada cultura material $\left.{ }^{2}\right)$.

Às mencionadas transformações (conceptuais, mas igualmente mentais e comportamentais) se reporta Neil Cossons, ao sublinhar: «Para um número crescente de pessoas, os engenhos e máquinas, fábricas, moinhos e armazéns, canais e vias férreas, que têm dominado a paisagem nos últimos dois séculos, têm-se tornado profundamente significativos como parte do seu patri-

(') Sobre o conceito de «monumento», ver Jacques Le Goff, -Documento / Monumento», Enciclopédia Einaudi, vol. 1: Memória-Hislória, Lisboa, Imprensa Nacional - Casa da Moeda, 1984, pp. 95-106.

$\left({ }^{2}\right)$ Cfr. Richard Bucaille e Jean-Maria Pesez, «Cultura material», Enciclopédia Einaudi, vol. 16: Homo-Domesticação. Cultura material, Lisboa, Imprensa Nacional - Casa da Moeda, 1989, pp. 11-47. 
mónio cultural» $\left({ }^{3}\right)$. Esta nova perspectiva sobre o património cultural já se começa igualmente a sentir entre nós, ainda que com alguma hesitação. Prova-o, por exemplo, a conhecida lei do património cultural português, algo de inovadora, no que se refere ao conteúdo, mas desactualizada, quanto à nomenclatura $\left({ }^{4}\right)$.

De acordo com o que, sucintamente, se acaba de expor, há que empreender acções de inventariação, estudo e preservação de toda uma série de monumentos, ainda não contemplados nos inventários e guias turístico-culturais. Assim, e para me reportar somente a Coimbra, além dos monumentos ou sítios sobejamente conhecidos pela sua beleza, antiguidade, importância e significado histórico (Universidade, Santa Cruz, Sé Velha e Sé Nova, mosteiro de Santa Clara-a-Velha, Quinta das Lágrimas, Jardim Botânico, Arcos do Jardim, etc), é imperioso ir chamando a atenção para diversos outros que, de igual modo, fazem parte integrante do património cultural conimbricense. Entre estes, poderão apontar-se: antigos estabelecimentos industriais (de lanifícios e sabões, em Santa Clara; de faiança e curtumes, na Baixa); estruturas, veículos e outro equipamento, da área dos transportes e comunicações; equipamentos colectivos, referentes ao abastecimento de água (antiga central elevatória, do Parque Dr. Manuel Braga), de electricidade (central termoeléctrica dos Serviços Municipalizados de Coimbra), mercados e casas de espectáculo. Trata-se de diversos monumentos industriais ( ${ }^{5}$ ), cujas potencialidades (culturais, didácticas, turísticas e mesmo económicas) urge aproveitar, antes que seja demasiado tarde. Como é do conhecimento geral, aqueles monumentos encontram-se permanentemente sob a ameaça de deterioração ou mesmo de demolição, em virtude não só da

( $^{3}$ Neil Cossons, The BP Book of Industrial Archaeology, 2. ${ }^{\text {a }}$ ed., Londres, David \& Charles, 1987, p. 13.

$\left({ }^{4}\right)$ Expressões como «património industrial», «monumento industrial» ou «monumento tecnológico» ainda não aparecem nela referidas (Lei 13/85, de 6 de Julho (Diário da República. I Série. n. ${ }^{\circ}$ 153. de 1985.07.06).

$\left({ }^{5}\right)$ Numa importante obra da especialidade, englobam-se no grupo dos «monumentos industriais» aqueles que «reflectem aspectos da transformação industrial, tecnológica e comercial» (Geoffrey D. Hay e Geoffrey P. Stell. Monuments of Industry. An Illustrated Historical Record, Glasgow, The Royal Commission on the Ancient and Historical Monuments of Scotland, 1986, p. VII). 
acção inexorável do tempo, mas também da indiferença dos responsáveis, para já não falar dos poderosos interesses económicos, por vezes em jogo. É um desses monumentos-concretamente a ex-Central Térmica dos Hospitais da Universidade de Coimbra (HUC) - que, seguidamente, me proponho focar.

\section{A CENTRAL TÉRMICA NO CONJUNTO DAS INSTA- LAÇÕES HOSPITALARES}

Os Hospitais da Universidade de Coimbra funcionaram durante décadas nos edifícios outrora pertencentes aos Colégios das Artes e de S. Jerónimo $\left({ }^{6}\right)$. Tratou-se de um processo de reutilização - a exemplo do que é hoje frequente, no âmbito da arqueologia industrial —, o qual se volta a repetir em nossos dias, após a desactivação daqueles edifícios (em 1987), com a transferência dos respectivos serviços hospitalares para o Novo Hospital. A relativa falta de adequação das instalações, por um lado, e a crescente procura dos serviços de saúde pela população, por outro, obrigaram a efectuar remodelações e acrescentos, com vista a torná-las mais funcionais. Na década de 1930, os HUC passavam exactamente por uma fase de profundas remodelações. Com efeito, pode ler-se no Plano geral de distribuição dos seus edifícios (1933-1934): «Os Hospitais da Universidade de Coimbra são constituídos por um conjunto de edifícios, dos quais, apenas dois se podem considerar concluídos, três estão presentemente em obras e cinco ainda em projecto» ( $\left.{ }^{\top}\right)$. Do mesmo Plano... consta o quadro transcrito (p. seg.).

$\left(^{6}\right)$ Numa placa, colocada no átrio do antigo edifício dos Hospitais da Universidade de Coimbra (na parte outrora pertencente ao Colégio de S. Jerónimo), encontra-se a seguinte inscrição: «Aqui existiram dois colégios universitários. No de S. Jerónimo, em 1848, instalaram-se as primeiras enfermarias; no Real Colégio das Artes, em 1853, o Hospital Universitário da Conceição».

«No ano de 1870 foram ambos os edifícios ocupados totalmente pelos Hospitais da Universidade de Coimbra que aqui funcionaram até 1987».

(') Ângelo da Fonseca. Hospitais da Universidade de Coimbra. Plano geral da distribuição dos seus edifícios (1933-1934), Coimbra, Direcção dos Hospitais da Universidade de Coimbra, 1934, p. 1. 
[PLANO GERAL DOS EDIFÍCIOS DOS HUC (1934)]

\begin{tabular}{|c|c|c|c|c|c|}
\hline & & Camas & Dispêndio & Orçado a dispender & Total \\
\hline Edifícios & concluídos: & & & & \\
\hline 1 & Lavandaria & 一 & $1460717 \$ 62$ & - & $1460717 \$ 62$ \\
\hline 2 & $\begin{array}{l}\text { Hospital do Castelo (Lázaros) Pavi- } \\
\text { lhão Nr. } 2\end{array}$ & 130 & $1375480 \$ 56$ & - & $1375480 \$ 56$ \\
\hline Edifícios & em obras: & & & & \\
\hline 3 & Hospital do Colégio das Artes & 471 & $562766 \$ 48$ & $684386 \$ 86$ & $1247153 \$ 34$ \\
\hline & Banco e Consultas Externas & 一 & $606116 \$ 18$ & $737533 \$ 04$ & $1343649 \$ 22$ \\
\hline 5 & $\begin{array}{l}\text { Hospital de S. Jerónimo - Quartos Par- } \\
\text { ticulares (pensionistas de } 1 .^{a} \text { e } \\
\text { 2 classe). Direcção, Secretaria, Casas } \\
\text { de Aulas, Electricidade Médica, Orto- } \\
\text { pedia, Mecanoterapia, etc. }\end{array}$ & 51 & $1246254 \$ 01$ & $734256 \$ 52$ & $1980510 \$ 53$ \\
\hline Edificios & a construir: & & & & \\
\hline 6 & Hospital do Castelo (Pavilhão Nr. 1) & 300 & -• & $3000000 \$ 00$ & $3000000 \$ 00$ \\
\hline 7 & Hospital do Castelo (Pavilhão Nr. 3) & 150 & - & $1500000 \$ 00$ & $1500000 \$ 00$ \\
\hline 8 & Novo Hospital de S. Jerónimo & 250 & - & $2500000 \$ 00$ & $2500000 \$ 00$ \\
\hline 9 & Central Térmica & 一 & - & $200000 \$ 00$ & $200000 \$ 00$ \\
\hline 10 & Maternidade & 150 & 一 & $1500000 \$ 00$ & $1500000 \$ 00$ \\
\hline & Totais & 1502 & $5251334 \$ 85$ & $10856176 \$ 42$ & $16107511 \$ 27$ \\
\hline
\end{tabular}

FONTE: Ângelo da Fonseca, Hospitais da Universidade de Coimbra. Plano geral da distribuição dos seus edifícios (1933-1934), Coimbra, 1934, p. 1. 
Como se verifica pelos respectivos dados, as obras a efectuar importariam em mais de 16000 contos, mas dotariam os Hospitais de uma capacidade total de 1502 camas. A ampliação dos HUC integrava-se numa estratégia mais vasta, a qual visava manter na Alta toda a actividade universitária e respectivos serviços a ela ligados. A propósito, sublinhava o Prof. Doutor Ângelo da Fonseca, então Director dos HUC: «É tendência moderna agrupar os edifícios destinados ao ensino superior, de forma a constituir cidades universitárias, e Coimbra presta-se admiravelmente a um empreendimento desta organização. Para isso, como já tivemos ocasião de referir, basta aproveitar o património de incalculável valor que herdamos, cheio de beleza arquitectónica e que constitui a nossa Universidade. Esta é somente pequena para satisfazer as exigências da ciência da época presente». E prossegue o Autor, dando o mote aos desígnios que presidiriam à edificação da nova cidade universitária: «Cada Faculdade tem de dilatar o perímetro da sua acção, actualizando os seus estudos, os seus serviços, os seus laboratórios, etc. Mas, tudo tem de ficar concentrado no Bairro Alto que, até por tradição, tem de ser séde da nossa cidade Universitária»( $\left.{ }^{s}\right)$.

Obviamente que esta perspectiva - concretizada pelo Estado Novo nos anos quarenta - teve o seu ponto fraco, designadamente na descaracterização e demolição de grande parte do património cultural da Velha Alta, contra o que, justamente, diversas vozes se têm levantado $\left({ }^{\circ}\right)$.

Como se constata pela análise do supracitado Plano geral de distribuição dos edifícios dos HUC em 1934 incluía-se, entre os cinco edifícios a construir, exactamente a Central Térmica, cujo orçamento atingia os $200000 \$ 00$. Sobre esta central, ocorre perguntar: quais as razões justificativas da sua construção, em edi-

$\left({ }^{8}\right)$ Ângelo da Fonseca, idem, p. 2 (sublinhado meu).

() A Velha Alta... Desaparecida. Álbum comemorativo das bodas de prata da Associação dos Antigos Estudantes de Coimbra, Coimbra, Livraria Almedina, 1984; Alta de Coimbra. História-Arte-Tradição. Actas do 1.0 Encontro sobre a Alta de Coimbra. Coimbra, 23, 24, 25 e 28 de Outubro de 1987, Coimbra, GAAC, 1988. 
fício próprio, afastado das restantes instalações hospitalares? Que papel lhe estava destinado, no respectivo contexto?

A edificação da Central Térmica impunha-se por três ordens de razões: falta de capacidade do sistema gerador de vapor, de que então se dispunha; localização deficiente, ilegal e perigosa das caldeiras a vapor em actividade; dispersão do equipamento gerador de vapor. Quanto ao primeiro e segundo aspectos, salienta-se, num ofício remetido pelos HUC ao Eng. Director dos Edifícios e Monumentos Nacionais: «Reconhecida a insuficiência de produção das antigas caldeiras, reconhecidas estas como velhas e cançadas [sic], reconhecida como ruinosa, perigosa e ilegal a respectiva instalação, desde 1937 passei a inscrever, nos orçamentos hospitalares, devidamente autorisado [sic], a verba para a compra de novas caldeiras» $\left({ }^{10}\right)$.

Com efeito, as referidas caldeiras tinham uma superfície de aquecimento de apenas $120 \mathrm{~m}^{2}\left({ }^{11}\right)$, enquanto a área das que lhe sucederam, com a instalação da nova central, atingiria os $330 \mathrm{~m}^{2}$ $\left(165 \mathrm{~m}^{2}\right.$ cada uma) $\left(^{12}\right)$. Sobre o assunto afirmava o Director dos HUC em 1940: «Em primeiro lugar, referirei que actualmente os serviços de vapôr são alimentados por duas velhas caldeiras, uma delas, apenas, com 50 metros quadrados de superfície de aquecimento, sendo o rendimento de ambas insignificante para o largo consumo de vapôr que algumas dependências destes Hospitais exigem, tais como as cosinhas [sic], a lavandaria, os serviços de desinfecções e esterelisações [sic], o aquecimento das salas de operações, das enfermarias, etc, etc». E acrescenta: «Sem o vapôr necessário, evidentemente, muitos trabalhos deixam de se fazer, apesar de ficarem sem aquecimento não só várias secções, como bastantes enfermarias» $\left({ }^{13}\right)$.

$\left({ }^{10}\right)$ Arquivo da Direcção dos Edifícios Nacionais do Centro (ADENC), Processo $n .^{\circ}$ 28, 1941-45, oficio de 1941.11.20.

(') Uma das caldeiras tinha $50 \mathrm{~m}^{2}$ de superfície de aquecimento, pelo que a superfície de aquecimento da outra seria de $70 \mathrm{~m}^{2}$ (ADENC, idem, ofício de 1940.01.26).

${ }^{\left({ }^{12}\right)}$ Arquivo da Direcção-Geral de Energia - Direç̧ão de Serviços Regional de Coimbra (ADGE/DSRC), Processo n. ${ }^{\circ} 1517$, ofício de 1951.11.16.

$\left({ }^{13}\right)$ ADENC, Processo n. ${ }^{\circ}$ 28, 1938-40, ofício de 1940.01.26. 
As referidas caldeiras, além da reduzida capacidade de resposta, encontravam-se instaladas em local inadequado e, inclusive, interdito pela legislação em vigor. Efectivamente, o Decreto n. ${ }^{\circ} 8332$ (de 1922.08.17) estipulava, no artigo 6. ${ }^{\circ}$ «Para as [caldeiras] de 1. " categoria: a instalação deve ser feita fora de casas de habitação ou de oficinas com andares por cima, em local onde só trabalhe permanentemente o pessoal de fogo» $\left({ }^{14}\right)$. A localização indevida das caldeiras - quer do ponto de vista legal, quer quanto à falta de segurança - era um argumento frequentemente utilizado, para justificar a construção da nova central térmica. Entre outras, merece ser evocada, pelo seu realismo e objectividade, a referência seguinte: «Permita-me V. Exc. " que venha chamar a sua atenção para a gravidade que representa a manutenção da nossa Central de Caldeiras Geradoras de vapor, no local em que se encontra. Por baixo de duas enfermarias onde se encontram hospitalizados centenas de doentes, V. Exc." pode prever o que seria uma explosão de uma caldeira de $120 \mathrm{~m}^{2}$ de superfície de aquecimento $\left({ }^{15}\right)$, trabalhando a 8 atmosferas. Não será demais prever que, além das centenas de mortes que tal desastre provocaria, de doentes de todas as idades e sexos, aquele lado do Edifício dos Hospitais ruiria por completo, causando ainda estragos irreparáveis no Laboratório Químico e respectiva aparelhagem, que se encontra em frente» $\left({ }^{16}\right)$. Mas a referida localização, além de perigosa, era ainda inconveniente, por antieconómica. Sobre o assunto, acrescenta-se, no documento acabado de citar: «Ainda sob o ponto de vista económico, o local em que a caldeira se encontra instalada é o mais impróprio; porquanto, sendo a cosinha [sic], o balneário e a lavandaria os primeiros consumidores do vapor produzido, esta encontra-se em um nível inferior e aquelas ao mesmo nível da caldeira, pelo que não é possível trazer o retorno fazendo o circuito fechado, perdendo-se assim muitos milhares de

$\left(^{14}\right)$ Diário do Governo, I Série, n. ${ }^{\circ}$ 167, de 1922.08.17.

$\left({ }^{15}\right)$ Como se verificou já, a referida superfície de aquecimento $\left(120 \mathrm{~m}^{2}\right)$ dizia respeito às duas e não apenas a uma das caldeiras.

${ }^{16}$ A DENC, Processo n. ${ }^{\circ}$ 28, 1938-40, ofício subscrito pelo ecónomo, A. Machado, datado de 1934.03.12. É interessante a alusão ao Laboratório Químico, dado o seu significado (artístico, científico e cultural) e raízes históricas que, como é sabido, remontam à época pombalina. 
calorias por hora, que, reduzidas a carvão, representam muitas centenas de quilos de carvão que diariamente se escapam livremente pelos tubos condutores do vapor» $\left({ }^{17}\right)$.

Relativamente à dispersão do equipamento gerador de vapor, ela devia-se ao facto de não existir, na altura, uma central térmica com capacidade suficiente para abastecer os variados sectores. «Além destas caldeiras [instaladas sob as enfermarias e já anteriormente referidas], encontram-se ainda a funcionar: duas pequenas caldeiras, a baixa pressão, para o aquecimento dos quartos particulares e dependências da Secretaria; uma outra pequena caldeira para o aquecimento das águas distribuídas pelos quartos particulares; e, ainda, uma outra caldeira de baixa pressão para o aquecimento das Salas de Operações e quartos particulares, algumas enfermarias, e salas de pensos do Hospital do Colégio das Artes. Há, pois, três centrais dispersas nos edifícios do Colégio das Artes e de S. Jerónimo, com manifesto prejuízo para o serviço, visto não disporem de pessoal suficiente e com prejuízo económico pela dispersão de combustível» $\left({ }^{18}\right)$.

Em suma: o aumento de capacidade dos HUC (que, como vimos já, passaria a dispor de 1502 camas), a ampliação e diversificação das instalações e a melhoria dos respectivos serviços (cada vez mais procurados) aconselhavam a que se edificasse uma única central térmica, não só dotada de capacidade suficiente - para responder às crescentes necessidades —, como ainda instalada em local que oferecesse segurança. Esperava-se assim que, com a nova central térmica, ficasse «centralizado num único ponto o fornecimento de vapor, águas quentes c aquecimento, aos edifícios do Colégio das Artes, S. Jerónimo, Banco e Consultas Externas, Lavandaria, Laboratórios, Cozinhas, futuro Hospital da cêrca de S. Jerónimo, etc.» $\left({ }^{19}\right)$.

Sobre a expectativa e o interesse que rodearam a questão das caldeiras / central térmica dos HUC, resta acrescentar que o assunto foi levado até às mais altas esferas políticas, desde o Ministro das Obras Públicas, Eng. ${ }^{\circ}$ Duarte Pacheco, ao próprio Presi-

(') Cfr. nota 16.

${ }^{\left({ }^{1}\right)}$ Ângelo da Fonseca, Hospitais da Universidade de Coimbra. Edifícios e serviços industriais, Coimbra, Imprensa da Universidade, 1933, p. 60.

(') Ângelo da Fonseca, ibidem. 
dente do Conse Com efeito, Duarte Pacheco, sobre o parecer emitido pelas Repartições de Estudos e Obras de Edifícios, relativo ao edifício da Central Térmica dos HUC, proferiu, em 13 de Agosto de 1941, o seguinte despacho: «Considero o problema bem orientado - Duarte Pacheco» $\left({ }^{20}\right)$. Relativamente à intervenção de Salazar, no que se refere à Central Térmica, informava o Director dos HUC, Prof. Doutor Ângelo da Fonseca, em ofício remetido ao Eng. Director Geral dos Edifícios e Monumentos Nacionais (1941.11.20): «Depois de algumas dificuldades resolvidas - graças à intervenção directa de Sua Excelência o Senhor Presidente do Conselho - a compra de novas caldeiras foi realizada em Novembro de 1939, à firma inglesa S.E. de C. Babcock \& Wilcox» $\left({ }^{21}\right)$.

Adquiridas as caldeiras, em finais de 1939, restava ainda solucionar um outro problema: a sua instalação. Para o efeito, havia que construir o respectivo edifício, o que efectivamente foi feito, até 1944. O facto de se estar, então, em plena II Guerra Mundial (1939-1945) trouxe alguns problemas à evolução dos trabalhos, nomeadamente quanto às dificuldades na aquisição de materiais e artigos de ferro e de aço.

2. EDIFÍCIO DAS CALDEIRAS: RESENHA HISTÓRICA

A localização foi o primeiro problema a solucionar, com vista à edificação da nova central térmica. Após a efectuação de estudos e atendendo aos pareceres emitidos pelos respectivos técnicos, optou-se pela «Cerca dos Jesuítas», mais concretamente por uma área situada junto à Rua Abílio Roque (actual Rua P. António Vieira) $\left({ }^{22}\right)$.

$\left.{ }^{(20}\right)$ ADENC, Processo n. ${ }^{\circ}$ 28, 1941-45, ofício de 1941.08.22 (sublinhado meu).

${ }^{(1)}$ ADENC, idem, ofício de 1941.11.20 (sublinhado meu).

${ }^{(2)}$ A referida rua teve a denominação de «Abílio Roque entre 1912 e 1942». Com efeito, «por deliberação camarária de 30-IV-1942 mudou-se a denominação de Rua Abílio Roque para Rua P. António Vieira». Sobre os motivos desta alteração, sublinhou José Pinto Loureiro: «As razões que 


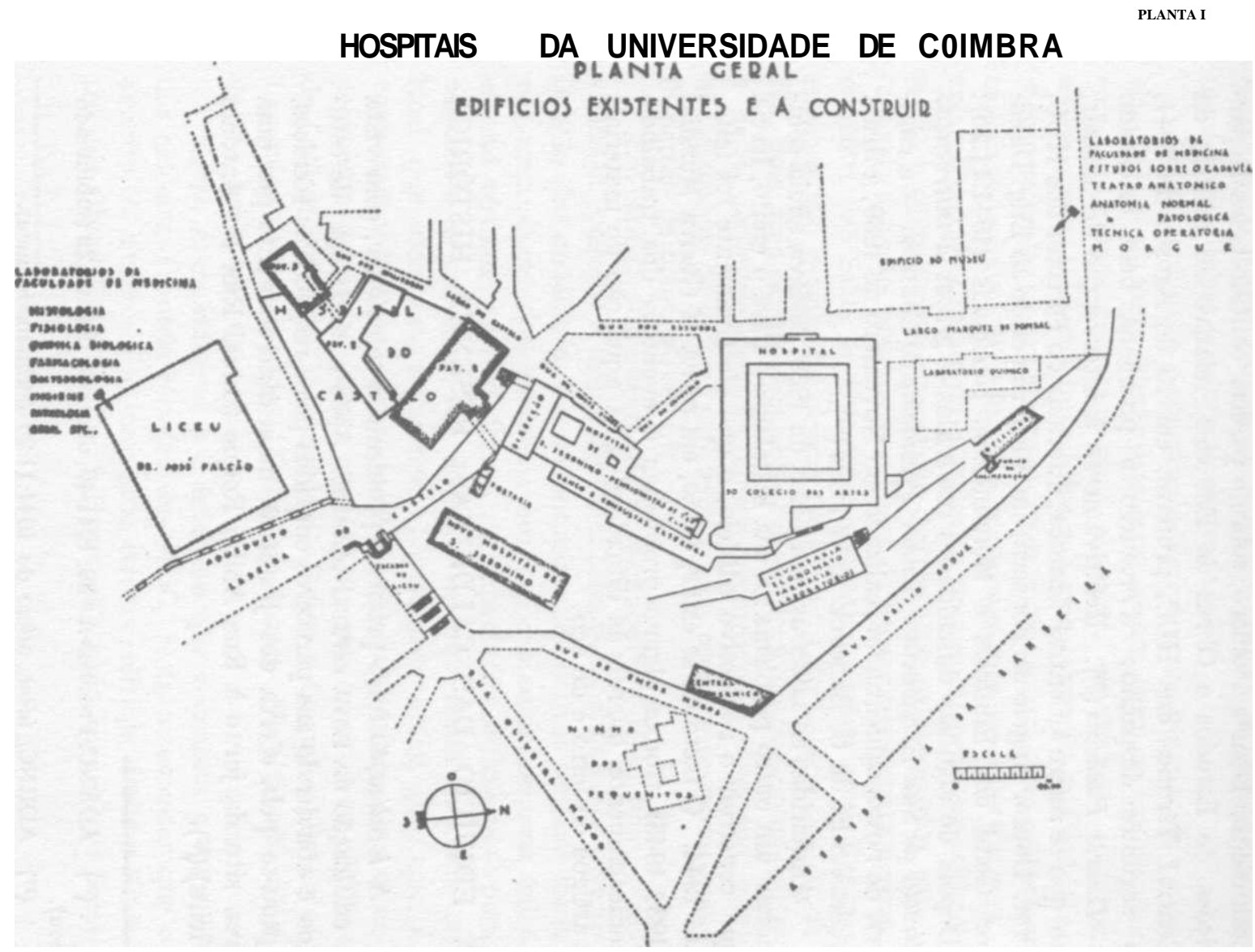

Fig. 1 - Planta de 1934, envolvendo o local de implantação das caldeiras (Central Térmica) (Hospitais da Universidade de Coimbra. Plano Geral de distribuição dos seus edifícios (1933-1934), Coimbra, 1934, planta 1). 
Embora a qualidade dos terrenos não fosse a mais aconselhável para a referida construção $\left({ }^{23}\right)$, para a sua escolha contribuíram decisivamente os seguintes factores: $\boldsymbol{a})$ o desnível em relação ao plano superior dos edifícios dos HUC, o que permitia o reaproveitamento das águas de retorno, do vapor condensado $\left({ }^{24}\right)$; b) o fácil acesso, relativamente ao carvão que iria ser transportado da Estação (Nova) de caminho-de-ferro para o local $\left({ }^{25}\right)$; $c$ ) a cedência do referido terreno pela Câmara Municipal de Coimbra, ainda que com a exigência de algumas contrapartidas. Sobre este último aspecto, informava a dita Câmara, em 1941: «A Câmara, no desejo de colaborar na obra hospitalar, resolveu em sua sessão de dezanove de Março de mil novecentos trinta e seis, o seguinte: - Propôr a cedência do Pôsto de desinfecção e respectivos terrenos anexos para a instalação da Central Térmica dos Hospitais da Universidade, ficando a cargo dos mesmos Hospitais os serviços de esterilizações, presentemente a cargo da Câmara, fornecimento gratuito de vapôr necessário para o edifício do Ninho dos Pequenitos e para uma Central de Pasteurização de leites a instalar pela

levaram a vincular a esta rua o nome do grande orador sagrado - o maior de todos os tempos - andam nos guias e roteiros, informando que na mata do cerco dos Jesuítas, cortada pela abertura desta rua, folgava o P. António Vieira de recrear-se em longas meditações, durante o tempo que passou no Colégio da sua ordem, nesta cidade» (José Pinto Loureiro, Toponímia coimbrã, I Parte, tomo I, Coimbra, Câmara Municipal, 1960, p. 107).

${ }^{23}$ ) Numa memória descritiva, referente ao orçamento suplementar, menciona-se «a inferior qualidade dos terrenos de fundação», o que contribuiu para aumentar os respectivos custos (ADENC, Processo n. ${ }^{28}$, 1941-45, Memória descritiva, de 1941-45).

$\left.{ }^{(24}\right)$ «A Central prevista deve ser instalada no fundo da cêrca dos Jesuítas, na Rua Abílio Roque, dando assim o declive indispensável para poderem ser aproveitadas as águas de retôrno do vapor condensado, as quais devem dar entrada novamente na caldeira com uma diferença de calorias não superior a $25^{\circ}$ entre a entrada e a saída» (Ângelo da Fonseca, Hospitais da Universidade de Coimbra. Edifícios e serviços industriais, p. 60; ADENC, Processo n. ${ }^{\circ}$ 28, 1938-40, ofício de 1934.03.12).

$\left.{ }^{(25}\right)$ «Ao fundo da íngreme encosta hospitalar e logo [à] entrada do que fôra a «Cerca dos Jesuítas», os Edifícios Nacionais haviam providenciado na construção de edifício próprio para a sua instalação, que só pecou pela localização em sítio escondido e obscuro, mas o imperativo, como é lógico, foi o de mais fácil acesso e descarga de combustível» (Luís Salatina, «As caldeiras Babcock», Boletim A Casa do Pessoal $\left[\mathrm{dos}\right.$ H U C], n. ${ }^{\circ}$, 1984, p. 11 ). 
Câmara» $\left({ }^{26}\right)$. As condições da cedência do referido terreno seriam posteriormente evocadas pela Câmara Municipal de Coimbra, numa altura em que a Direcção dos Edifícios do Centro oficiara para que a Câmara removesse, do edifício da Central Térmica, as espias e os fios de protecção da linha aérea da tracção eléctrica $\left({ }^{27}\right)$.

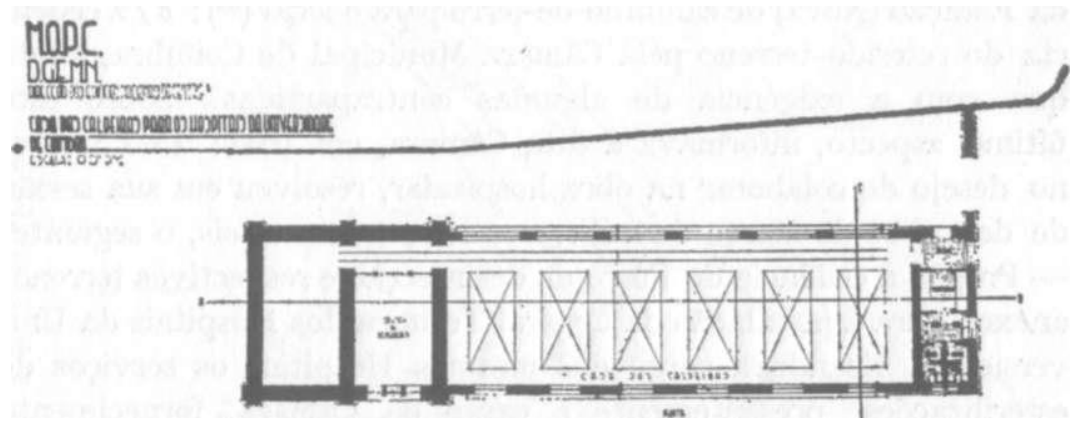

Fig. 2 - Planta de implantação do espaço onde se encontram instaladas as caldeiras (Direcção dos Edifícios Nacionais do Centro, processo n. ${ }^{\circ} \mathbf{2 8}$; fot. de Varela Pècurto).

Escolhido o terreno, foi elaborado, em 1940, o ante-projecto do edifício em questão. Da elaboração do projecto foram incumbidos o Eng. ${ }^{\circ}$ Artur Martins Freire de Andrade Pimentel e o Arq. Alfredo Duarte Leal Machado. Este já anteriormente (1938) se havia pronunciado sobre o tipo de edifício mais adequado, ao sublinhar: «...bastando dizer somente que tratando-se de uma construção industrial se pretende fazer uma construção o mais sóbria e modesta possível» $\left({ }^{28}\right)$.

${ }^{(26}$ ) A DENC, Processo $n .^{\circ}$ 28, 1941-45, ofício dirigido pela Câmara Municipal de Coimbra ao Director dos Edifícios e Monumentos Nacionais — Lisboa, em 1941.01.07.

${ }^{(27)}$ A Câmara Municipal de Coimbra recordava que o terreno fora cedido gratuitamente e sem qualquer compensação (ADENC, idem, ofício de 1942.04.30). Como se constata pela citação efectuada no texto, ainda que efectivamente sem qualquer compensação monetária, houve, de facto, as contrapartidas indicadas.

$\left.{ }^{(28}\right)$ A DENC, Processo n. ${ }^{\circ}$ 28, 1938-40, Relatório, transcrito numa Memoria descritiva e justificativa, datada de 1938.02.24. 
O respectivo concurso foi aberto em finais de 1940 , tendo sido divulgado em alguns jornais diários $\left({ }^{29}\right)$. Com uma base de licitação de 192 299\$22, o concurso público da respectiva empreitada foi marcado para 6 de Dezembro daquele ano $\left({ }^{30}\right)$. Concorreram dois indivíduos e uma firma:

- Bernardo Teles, de Coimbra

$191799 \$ 00$

- António Maia, de Coimbra

$189900 \$ 00$

- Lourenço Simões \& Reis, Lda., de Lisboa $191700 \$ 00\left(^{31}\right)$

O concurso foi ganho por António Maia, construtor civil de Coimbra (residente em Santo António dos Olivais), pois foi ele quem apresentou valores mais baixos (189900\$00), para a execução da referida empreitada. Da dita importância, $159900 \$ 00$ (84\%) correspondiam ao custo dos materiais, enquanto $30000 \$ 00$ $(16 \%)$ diziam respeito à mão-de-obra $\left({ }^{32}\right)$.

O edifício da Central Térmica, segundo o projecto, tinha as seguintes dimensões: exteriores - 39,60 X $16,80 \mathrm{~m}$; interiores (entre paredes) - $38 \times 16 \times 11 \mathrm{~m}$, respectivamente de comprimento, largura e altura $\left({ }^{33}\right)$.

Não obstante tratar-se de uma construção industrial, logo «o mais sóbria e modesta possível»-como sublinhou o citado Arq. A. Leal Machado-, as respectivas obras arrastar-se-iam por cerca de três anos (1941-1944). Com efeito, aquelas tiveram início em 1 de Junho de 1941 e só ficaram concluídas em 3 de Março

$\left(^{29}\right.$ Diário de Coimbra, de 1940.11.29; Primeiro de Janeiro, de 1940.11.30.

( $\left.{ }^{30}\right)$ Diário de Coimbra, de 1940.11.29.

${ }^{(1)}$ A DENC, Processo n. ${ }^{\circ}$ 28, 1938-40, ofício remetido ao Director do jornal $O$ Boletim de Informações (Rua dos Correeiros, $n .^{\circ}$ 15-3. ${ }^{\circ}$-Lisboa), em 1940.12.09.

$\left.{ }^{32}\right)$ ADENC, Processo n. ${ }^{\circ}$ 28, 1941-45, cópia do texto publicado no Diário do Governo, II Série, de 1941.05.28. No que se refere à mão-de-obra, para se avaliar mais concretamente o seu peso relativo no conjunto da obra, é necessário ter em conta os níveis dos salários, relativamente baixos, então praticados. Com efeito, o construtor António Maia comprometera-se (1940.12.06) a pagar os seguintes salários mínimos: serralheiro e pintor - 14\$00; carpinteiro-12\$00; pedreiro - 11\$00; trabalhador $-7 \$ 50$; e servente (menores) $-\mathbf{5 \$ 0 0}$ (ADENC, Processo n. ${ }^{\circ} \mathbf{2 8}, 1938-40$ ).

(" ADENC, idem, ofícios de 1940.02.22 e de 1940.08.03. 
de $1944\left({ }^{34}\right)$. São frequentes os testemunhos relativos ao arrastamento das obras, bem como sobre a urgente necessidade de as concluir com a máxima rapidez. Entre outros motivos (referentes, por exemplo, à aludida deficiente instalação dos geradores de vapor), mencionava-se a urgência de instalar devidamente e ensaiar as caldeiras, entretanto chegadas da Grã-Bretanha (o que já se verificava em inícios de 1941) $\left({ }^{35}\right)$. Assim, em Outubro deste ano, a Direcção dos HUC declarava, em ofício dirigido ao Eng. Director dos Edifícios Nacionais do Centro: «Parece que estes derradeiros dias de sol deveriam ser aproveitados no avanço das obras e cobertura do edifício, a fim de tão cedo quanto possível se fazer a remoção de material valiosíssimo que quasi se encontra desprotegido nas cêrcas destes Hospitais. Infelizmente tem-se a impressão que as obras paralisaram para recomeçarem, talvez, em pessimas condições de tempo» $\left({ }^{36}\right)$.
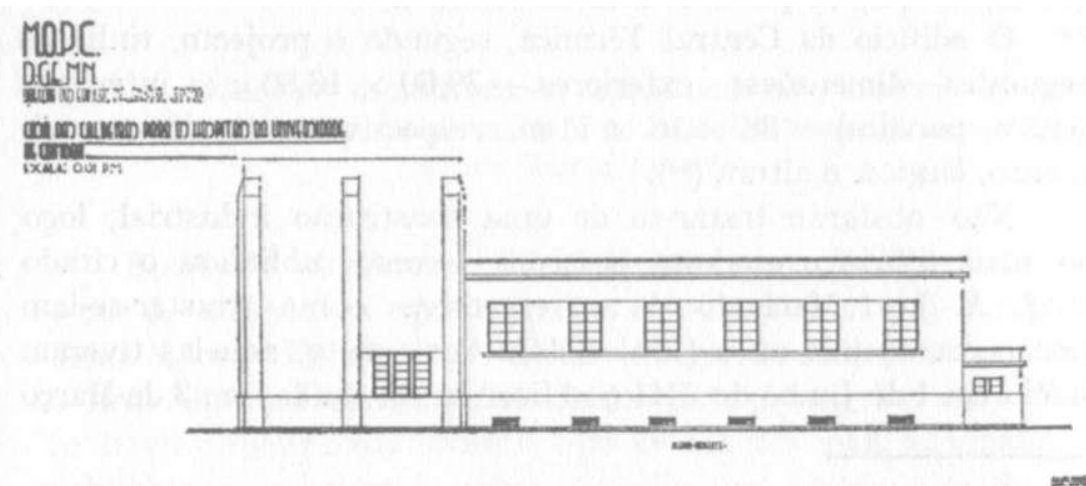

Fig. 3 - Alçado nascente do edifício das caldeiras, sensivelmente voltado para os actuais jardins interiores da Associação Académica de Coimbra (Direç̧ão dos Edifícios Nacionais do Centro, processo n. ${ }^{\circ} 28$; fot. de Varela Pècurto).

Os atrasos verificados na construção das instalações da Central Térmica eram imputados ao mau tempo-particularmente

$\left(^{34}\right)$ ADENC, Processo n. ${ }^{\circ}$ 28, 1941-45, ofício de 1941.08.25.

$\left({ }^{35}\right)$ ADENC, idem, ofícios de 1942.03.10 e de 1944.03.03.

${ }^{36}$ ADENC, idem, ofício registado na Direcção dos Edifícios Nacionais do Centro, em 1941.10.18. 
no Inverno-, às dificuldades em obter certos materiais, como ferro e aço (efeitos da II Guerra Mundial, como já se disse), mas também ao próprio empreiteiro, António Maia. Este, a despeito da sua competência e já longa experiência $\left({ }^{37}\right)$, não acompanhava os trabalhos de perto como seria necessário, devido a outros empreendimentos em que se encontrava empenhado. A propósito, acentuava-se num ofício remetido ao Director dos HUC: «O adjudicatário, empreiteiro António Maia, que tomou esta empreitada por estima e consideração por V. Exc." , está quasi sempre em Lisboa onde tem em curso trabalhos de vulto. O Snr. Ventura é que acompanha a empreitada, ignorando, certamente o Snr. António Maia o rumo que as coisas levam» $\left({ }^{38}\right)$.

Em meados de 1941, trabalhavam nas obras da Central Térmica 29 operários, «encontrando-se as cantarias quasi todas efectuadas, as fundações concluídas na quasi totalidade e as paredes em elevação em construção» $\left({ }^{39}\right)$. Contudo, devido ao mau tempo (Maio e princípio de Junho de 1941) e ao facto de ter sido necessário aprofundar as fundações $\left({ }^{40}\right)$, os trabalhos não progrediam a ritmo desejado, o que mereceu o seguinte comentário, da Direcção dos HUC: «E passou-se o ano de 1940, o verão e o explêndido [sic] outono de 1941 e vislumbram-se umas paredes levantadas, por telhar. Parece ter-se passado tão explêndido [sic] tempo em estudos de cobertura. Tem-se a impressão que as obras paralizaram» $\left({ }^{41}\right)$.

$\left({ }^{37}\right)$ A afirmação baseia-se nos seguintes elementos: por um lado, António Maia havia sido aprovado, por unanimidade e com a classificação de ВОМ (1915), para o serviço de inspecção e vigilância para segurança das reparações de construções civis; por outro, na relação dos diversos trabalhos que dirigira, da qual constavam os seguintes: construção do novo edifício dos Correios e Telégrafos, em Coimbra; construção e acabamento do Liceu Dr. Júlio Henriques, em Coimbra; construção do novo edifício do Banco dos Hospitais da Universidade de Coimbra; conclusão do novo edifício dos Correios e Telégrafos, em Viseu; ampliação do Liceu D. João III, em Coimbra. Além destes, «tem feito muitas obras particulares e está a construir o novo edifício para os Correios, Telégrafos e Telefones, na Figueira da Foz (ADENC, Processo n. ${ }^{\circ}$ 28, 1938-40, docs. de 1940.04.26 e de 1940.12.06).

$\left.{ }^{38}\right)$ ADENC, Processo n. ${ }^{\circ}$ 28, 1941-45, ofício de 1941.07.25.

( $\left.{ }^{39}\right)$ ADENC, ibidem.

${ }^{40}$ ADENC, idem, ofício de 1941.07.25.

( $\left.{ }^{41}\right)$ DENC, idem, ofício de 1941.11.20. 
Mas para o funcionamento da nova Central Térmica, além do edifício, para instalação das caldeiras, e do reservatório para o carvão, era indispensável construir a chaminé. Daí que, a partir de finais de 1941, paralelamente à continuação das obras do edifício, se começasse a prestar mais atenção aos assuntos relativos à chaminé, complemento essencial da Central Térmica. Entre outros, salientavam-se os referentes à localização e às dimensões.

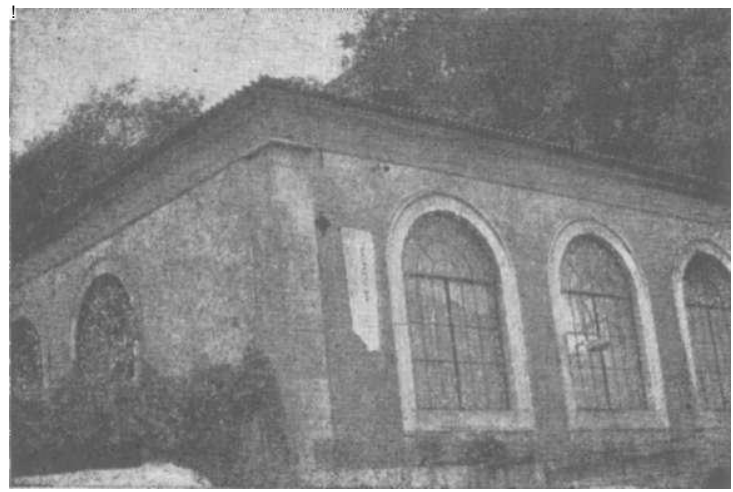

Fig. 4 - Vista de um dos gavetos da construção (Norte-Nascente), sendo de realçar o enquadramento arquitectónico exterior das janelas (fot. de J. Amado Mendes).

Quanto à localização, admitiram-se duas hipóteses:

1. - «A chaminé ficaria colocada, encostada à fachada do Edifício de S. Jerónimo e ligada a chapas por um colector is olado»;

2. " - «...junto da casa das caldeiras, dando à chaminé uma altura suficiente a fim de que os Edifícios dos Hospitais não fossem afectados pelos gases, razão pela qual a altura conveniente era de 60 metros». Esta era a solução preferida pela casa «Babcock», fornecedora das caldeiras $\left({ }^{42}\right)$.

Tanto a localização como a altura da chaminé, além dos aspectos eminentemente técnicos, colocavam problemas de deli-

(42) A D E G E / DSRC, Processo n. ${ }^{4}$ 1517, relatório datado de 1951.04.24. 
cada solução, devido aos seus efeitos poluidores na atmosfera, resultantes da queima de carvão. Ao assunto se refere um relatório, elaborado no âmbito da Direcção Geral hos Combustíveis: «No caso da chaminé ser colocada junto da casa das caldeiras as suas dimensões seriam: altura $60 \mathrm{~m}$. No caso da solução detenida [sic] no caderno de encargos: altura $32 \mathrm{~m}$. Não foi efectuada nenhuma destas soluções, porquanto a chaminé existente está situada junto da casa das caldeiras e tem somente 8,5 metros de altura» $\left({ }^{43}\right)$.

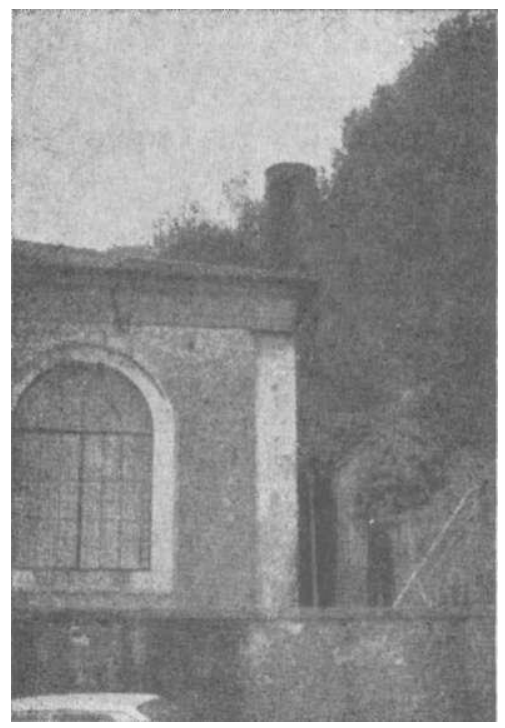

Fig. 5 - Vista do cunhal Norte-Poente e, em segundo plano, da parte superior da chaminé (fot. de J. Amado Mendes).

A solução adoptada viria a revelar-se bastante gravosa para o meio ambiente, dando origem a uma série de protestos dos moradores vizinhos e da própria Direcção dos HUC. A fim de atenuar o elevado grau de poluição atmosférica, nos inícios dos

$\left({ }^{43}\right)$ ADGE / DSRC, ibidem. 
anos 50 (mais precisamente, em 1953) as caldeiras, após as devidas alterações, passaram a consumir fuel-oil, em vez de carvão. Voltarei, oportunamente, ao assunto.

Efectuado o respectivo estudo geológico para a construção da chaminé (1942) $\left({ }^{44}\right)$, procedeu-se à sua edificação, para a qual foi obtida dispensa do concurso público $\left({ }^{45}\right)$. A própria firma vendedora das caldeiras - S. E. de C. Babcock \& Wilcox-fez algumas recomendações de carácter técnico, sobre a construção da chaminé e respectiva conduta $\left({ }^{46}\right)$.

De fins de 1942 a inícios de 1944, efectuaram-se os acabamentos das instalações da futura Central Térmica. Foi então que surgiram várias dificuldades, quanto à aquisição de certos materiais. Assim, foi difícil adquirir ferro para vigas, coberturas, etc, bem como para portas e caixilharia das janelas. Para obviar a estas dificuldades, o construtor chegou a solicitar autorização para executar certos trabalhos em madeira, mas isso não the foi autorizado. Em ofício da Direcção dos Edifícios Nacionais do Centro, o Eng. ${ }^{\circ}$ Chefe da 3." Secção sublinhava: «...e m minha opinião não deve ser satisfeito o pedido do interessado porque: a pretendida execução dos portões em madeira e ferro muito prejudicará o aspecto arquitectónico do edifício; dado o facto de não ser muito elevada a quantidade de ferro a empregar, parece-nos provável que o empreiteiro encontre quem execute o trabalho desde que

$\left({ }^{44}\right)$ O referido estudo geológico foi efectuado pelo Eng. ${ }^{\circ}$ Adriano Pinto dos Santos (ADENC, Processo n. ${ }^{\circ}$ 28, 1941-45, ofícios de 1941.12.31 e de 1942.01.12).

${ }^{(4)}$ Em 8 de Janeiro de 1942, o Tribunal de Contas visou o despacho ministerial que dispensava das formalidades de concurso público e do contrato escrito os trabalhos de construção da conduta e chaminé da Casa das Caldeiras dos HUC, para o que foi concedida a dotação de $13765 \$ 34$, por portaria de 1941.12.31 (ADENC, idem, ofício de 1942.01.14).

${ }^{46}$ «Foi adoptada para a conduta por estas razões uma secção rectangular estreita, sendo as suas dimensões interiores $1066 \mathrm{~mm} \quad[\ldots]$ de largura x $3048 \mathrm{~mm}$ (10 pés) de altura [...] No que diz respeito à chaminé, esta deverá ter um diâmetro de $1830 \mathrm{~mm}$ (6 pés) no tôpo. Este diâmetro é dado prevendo já o futuro trabalho de 3 caldeiras» (ADE NC, Processo n. ${ }^{\circ} 28$, 1938-40, ofício de 1940.02.22). 
consulte nesse sentido todas as casas da especialidade» $\left({ }^{47}\right)$. Os portões e caixilhos das janelas foram, efectivamente, construídos em ferro, o que não só valorizou a construção como, ainda hoje, continua a beneficiar o edifício, do ponto de vista do património industrial.

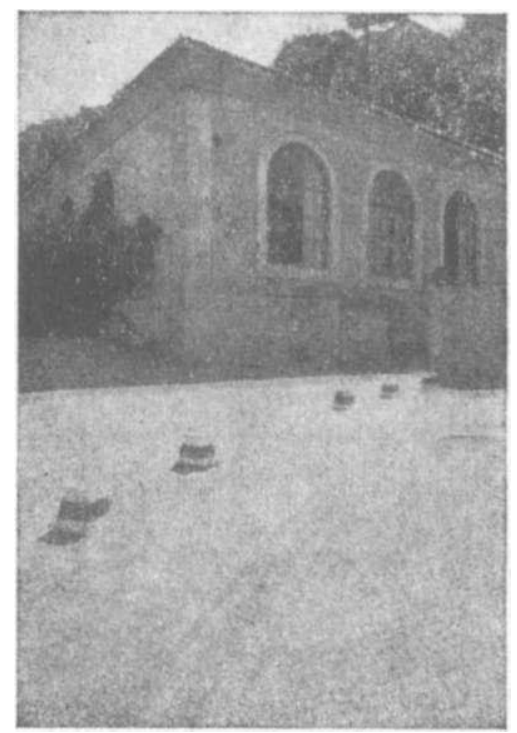

Fig. 6 - Fachada voltada a Norte, destacando-se o enquadramento das janelas (fot. de Varela Pècurto).

Igualmente a instalação eléctrica se encontrava atrasada, em inícios de 1943, devido às dificuldades de se adquirir o tubo de aço necessário para o efeito $\left({ }^{48}\right)$. Eram, afinal, os efei-

${ }^{47}$ ADENC, Processo n. ${ }^{\circ}$ 28, 1941-45, ofício de 1941.08.11. É provável que, como a certa altura foi sugerido, se tivesse recorrido a alguma casa especializada de Lisboa para a execução dos referidos trabalhos em ferro. Todavia, não se encontraram elementos que permitam, para já, esclarecer o assunto.

${ }^{48}$ ADENC, Processo n. ${ }^{\circ}$ 28, 1941-45, ofício de 1943.02.18. A Casa Caetano da Cruz Rocha (da Rua Ferreira Borges, em Coimbra) podia, contudo, fornecer material eléctrico para completar a dita instalação ( ADENC, idem, ofício de 1943.02.19). 
tos da economia de guerra, a repercutirem-se também em Portugal.

Finalmente, em Março de 1944, os trabalhos das instalações da Central Térmica estavam concluídos, à excepção de alguns acrescentos posteriores, designadamente o vestiário e as instalações sanitárias, cuja memória descritiva data de Junho do ano seguinte $\left({ }^{49}\right)$. Com efeito, em 5 de Maio de 1944, o Eng. ${ }^{\circ}$ Chefe da 3." Secção (Direcção dos Edifícios Nacionais do Centro) comunicava ao Eng. ${ }^{\circ}$ Director: «...tenho a honra de informar que a entrega do edifício da Central Térmica dos Hospitais da Universidade de Coimbra, poderá fazer-se no próximo dia 11 [de Maio de 1944], pelas $14 \mathrm{~h}$. e $30 \mathrm{~m} . »\left({ }^{50}\right)$.

Mas para que o edifício se transformasse em central térmica, era necessário dotá-lo da respectiva tecnologia, constituída essencialmente pelas caldeiras geradoras de vapor. É destas que, seguidamente, passarei a ocupar-me.

\section{EQUIPAMENTO TECNOLÓGICO}

Antes de focar propriamente as caldeiras da nova Central Térmica, atente-se no equipamento que as antecedeu, o qual, como já se frisou, se encontrava disperso pelos edifícios dos HUC.

Numa primeira fase (1914-1928), a produção de vapor e de energia eléctrica estiveram associadas. Para o efeito, em 1914 foi adquirida e montada uma caldeira semi-fixa, marca «Garrett», com $16 \mathrm{~m}^{2}$ de superfície de aquecimento. Logo em 1916, tendo-se a referida caldeira revelado insuficiente, ficou reservada apenas para o funcionamento de energia eléctrica, adquirindo-se uma nova geradora de vapor (uma caldeira fixa, marca «Babcock», com $55 \mathrm{~m}^{2}$ de superfície de aquecimento). Entretanto, os serviços hospitalares continuavam a expandir-se, pelo que, em finais dos anos vinte, já a capacidade de resposta das duas caldeiras se mostrava insuficiente. Como informa Ângelo da Fonseca, Director dos HUC - que sigo de perto, no que se refere aos antecedentes tecnológicos

(") ADENC, idem.

${ }^{\left({ }^{\circ}\right)}$ ADENC, idem, ofício de 1944.05.05. 
das caldeiras - , no período de 1916 a 1928 desenvolveram-se (ou criaram-se) diversos serviços. Assim, «novos laboratórios e outros serviços foram criados. Adquiriu-se uma nova cozinha a vapor, prevendo-se uma população futura de 1000 doentes; instalou-se uma lavandaria mecânica com aquecimento directo por vapor; levou-se o vapor a todo o edifício do Colégio das Artes, para poderem ser feitas esterelizações [sic] nas enfermarias; tornou-se necessário ampliar a Central de Esterelizações [sic] aquecer devidamente as salas de operações, casas de pensos, etc.» $\left.{ }^{51}\right)$.

Como a questão da energia eléctrica ficou solucionada, a partir do momento em que o seu funcionamento passou a ser assegurado pelos Serviços Municipalizados de Coimbra $\left(^{52}\right)$, havia que dotar os HUC com adequado equipamento gerador de vapor. Foi o que se fez, em 1928: «Adquiriu-se então na Alemanha, à firma Christoph \& Unnack A. G., uma caldeira com $120 \mathrm{~m}^{2}$ de superfície de aquecimento, 12 atm[osferas] de pressão, e um economizador de grande capacidade de água, que se montou ao lado desta caldeira para aproveitar tôdas as calorias que se escapam da câmara de fumo e que vão aquecer a agua no economizador, antes de saírem pela chaminé. Esta água, assim aquecida, vai abastecer em grande parte a própria caldeira e o balneário, sem que o seu aquecimento custe um único centavo ao Estado» $\left({ }^{53}\right)$.

Nos inícios da década de 1940, a questão dos geradores de vapor volta a colocar-se, pelo que as velhas caldeiras são ainda mencionadas. Efectivamente, o Director dos HUC comunica (em 1941.05.17) ao Eng. ${ }^{\circ}$ Director dos Edifícios Nacionais do Centro: «Segundo comunicação que acaba de me ser presente, a Caldeira Christoph Unmack, em serviço nestes Hospitais desde 1929 [adquirida, como se referiu, no ano anterior], carece de reparação urgente, tendo paralizado [sic] a produção. Há assim necessidade

$\left({ }^{51}\right)$ Ângelo da Fonseca, Hospitais da Universidade de Coimbra. Edifícios e serviços industriais, p. 59.

$\left({ }^{52}\right)$ Esse fornecimento deve ter-se iniciado nos anos 20, o mais tardar até 1928. «A primeira caldeira fornecia vapor e força motriz, e a terceira [adquirida em 1928] fornece unicamente vapor, visto que a energia eléctrica para a luz e força motriz é fornecida pelos Serviços Municipalizados de Coimbra que nos últimos seis meses de 1932 forneceram $67503 \mathrm{Kwh}$, e nos dois primeiros meses de 1933, $25540 \mathrm{Kwh}$ » (Ângelo da Fonseca, idem, p. 60).

( $\left.{ }^{53}\right)$ Ângelo da Fonseca, ibidem. 
de lançar mão de uma velha Babcock, comprada em $1912\left({ }^{54}\right)$, de capacidade insignificante, que alimentará as cozinhas e, muito mal, a Rouparia e Lavandaria. Ficam sem qualquer garantia de funcionamento os serviços de esterelizações [sic], de sala de operações, do Balneario, Laboratorios, etc, etc». E prossegue o Director dos HUC: «Regista-se desta forma uma situação muito seria a que ha muito esta Direcção procurou obstar com a compra e instalação de novas caldeiras» $\left({ }^{55}\right)$. Estas constituíam a terceira e última geração de caldeiras a funcionar na ex-Central Térmica dos HUC, as quais estiveram em actividade mais de quatro décadas (meados dos anos 40-1987).

Sobre as mencionadas caldeiras, poder-se-á perguntar: de que tecnologia se tratava? Quando, onde e em que condições foram adquiridas? Que vantagens trouxe a respectiva utilização?

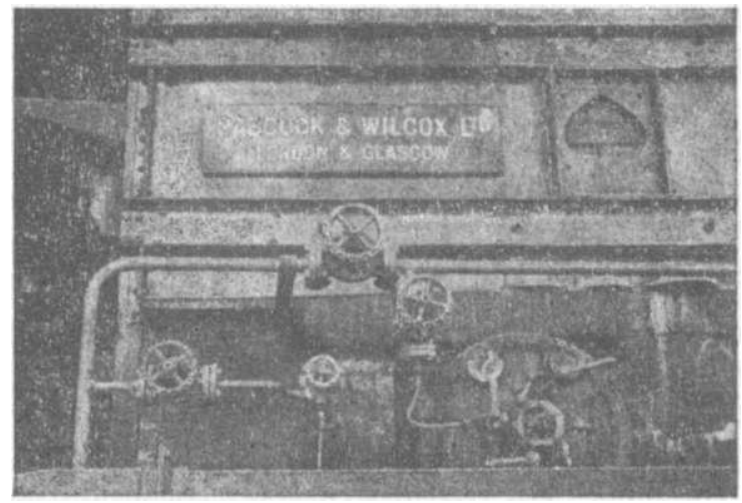

Fig. 7 - Pormenor de uma das caldeiras, do qual se destaca a respectiva marca (fot. de Varela Pècurto).

Tal como em 1916, continuou a optar-se pela marca «Babcock» ou, mais precisamente, «BABCOCK \& WILCOX». Cada uma

$\left.{ }^{\left({ }^{4}\right.}\right)$ Certamente há lapso no documento transcrito, pois o ano de aquisição da dita caldeira, já anteriormente citado, terá sido o de 1916 (cfr. nota 51).

$\left.{ }^{55}\right) \quad$ ADENC, Processo n. ${ }^{\circ}$ 28, 1941-45, ofício de 1949.05.17. 
das (duas caldeiras) adquiridas tinha as seguintes caracte rísticas:

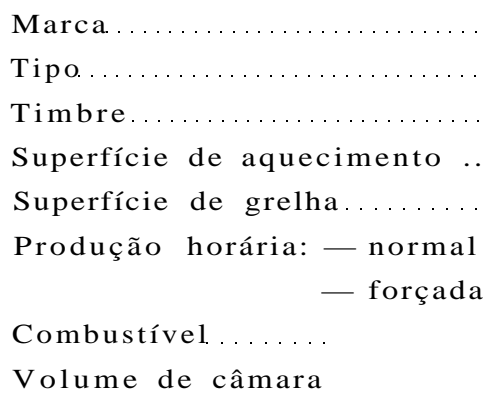

Babcock \& Wilcox $\mathrm{D}$

$$
\begin{aligned}
& 12 \mathrm{Kg} / \mathrm{cm}^{2} \\
& 165 \mathrm{~m}^{2} \\
& 6,75 \mathrm{~m}^{2} \\
& 2500 \mathrm{Kg} / \mathrm{h} \\
& 3000 \mathrm{Kg} / \mathrm{h} \\
& \mathrm{Cabo} \mathrm{Mondego} \\
& 11 \mathrm{~m}^{3}\left({ }^{56}\right)
\end{aligned}
$$

Tratava-se de uma tecnologia patenteada (em 1867) por G. H. Babcock e S. Wilcox, posteriormente aperfeiçoada e desenvolvida $\left({ }^{57}\right)$. Entre nós, várias empresas haviam já adquirido tecnologia da mesma marca $\left({ }^{58}\right)$. As ditas caldeiras vieram da Grã-Bretanha, datando o respectivo contrato de fornecimento de Novembro de $1939\left({ }^{59}\right)$. Em 5 de Janeiro do ano seguinte, o Director dos HUC informava o Director dos Edifícios Nacionais do Centro: «Tenho a honra de comunicar a V. Exc." que estes Hospitais contrataram com a casa Babcock \& Wilcox o fornecimento de duas grandes caldeiras geradoras de vapôr [...]. As duas caldeiras devem dar entrada neste estabelecimento, em condições de ser montadas, dentro de 10 meses» $\left({ }^{60}\right)$. O material chegaria a Portugal, por via marítima, de meados de 1940 a inícios de 1941. Com efeito, em 7 de Junho daquele ano era comunicada a chegada, ao Porto, da primeira remessa de material das caldeiras. Assim,

$\left({ }^{56}\right)$ A D G E / D S R C, Processo n. ${ }^{\circ}$ 1517, docs. de 1951.11.16 e de 1951.12.28.

$\left(^{(57}\right) \quad$ Cfr. Charles Singer et al., (eds.), A History of Technology, vol. v: The Late Nineteenth Century. C. 1859 to c. 1900, Oxford, Clarendon Press, 1967, pp. 137-138.

$\left({ }^{58}\right)$ Podem citar-se, entre outras, empresas sediadas em Campanhã e em Setúbal (U.E.P.); Fábrica de Fiação e Tecidos de Crestuma; Central da Companhia de Carris de Ferro, do Porto (ADEnC, Processo n. ${ }^{\circ}$ 28, ofício de 1941.11.20) e ainda a Empresa de Papel do Caima e a Central Tejo.

$\left({ }^{59}\right)$ ADENC, Processo n. ${ }^{\circ}$ 28, 1941-45, ofício de 1941.11.20.

$\left({ }^{60}\right)$ ADENC, Processo n. ${ }^{\circ}$ 28, 1938-40, ofício de 1940.01.15. 
haviam chegado à «Alfândega do Porto, 169 volumes, contendo 45 peças das duas caldeiras de vapor expedidas de Londres pela Casa Babcock \& Wilcox». Consequentemente, tornava-se ainda mais urgente a construção do edifício da Central Térmica - como se indicou, na alínea anterior deste trabalho - «por não haver [nos] Hospitais onde armazenar e instalar as caldeiras, como urge, para se proceder a experiências prévias, só possíveis, após a sua montagem, e indispensáveis para o respectivo pagamento àquela Firma» $\left({ }^{61}\right)$.

Por seu turno, o último embarque de material, remetido por Babcock \& Wilcox, teve lugar em Janeiro de 1941. Tratava-se de dois manómetros, trazidos pelo navio «Procris» $\left({ }^{62}\right)$. Em Maio do mesmo ano, já todo o material, pertencente às caldeiras, se encontrava em Portugal. Se a respectiva importação das caldeiras não se tivesse efectuado nos inícios do conflito - mesmo antes de haver edifício para as instalar —, novas dificuldades surgiriam. A propósito, afirma o Eng. ${ }^{\circ}$ António da Mota Coelho, dirigindo-se (1941.05.20) ao Director dos HUC: «Desta forma poderá ser utilisado [sic] o material, hoje impossível de obter, que V. Exc. ${ }^{a}$ com tão inteligente providencia encomendou a tempo e horas e já se encontra dentro dos Hospitais à espera de aplicação» $\left({ }^{63}\right)$.

Como é sabido, durante a II Guerra Mundial e anos imediatos, a problemática dos combustíveis revestiu-se de enorme importância. Com efeito, o preço e/ou escassez de certos combustíveis induziu o estudo e, em certos casos, o consumo de energias alternativas. Entre outros, podem apontar-se os seguintes exemplos: a substituição da lenha pelo fuel-oil, em certas fábricas vidreiras;

( ${ }^{61}$ ADENC, idem, ofício de 1940.06.07.

$\left({ }^{62}\right)$ ADENC, Processo n. ${ }^{\circ}$ 28, 1941-45, ofício de 1941.08.25.

$\left({ }^{63}\right)$ A DENC, idem, ofício de 1941.05.20. Luís Salatina narra algumas das peripécias que terão rodeado o transporte das caldeiras, de Londres para Coimbra (Luís Salatina, «As caldeiras Babcock», A Casa do Pessoal [dos HUC], n. ${ }^{\circ}$ 4, 1984, pp. 10-11). A documentação consultada é omissa, quanto ao assunto. Porém, no que se refere à cronologia, os elementos compulsados confirmam a vinda das caldeiras para Coimbra, essencialmente no segundo semestre de 1940 e não no Outono de 1939, como indica o Autor citado. Aliás, o próprio ano de construção (1940) encontra-se documentado (ADGE/DSRC, doc. de vistoria, de 1953.10.26). 
tentativas no uso do gás, em vez de gasolina, no transporte automóvel. No que à Central Térmica dos HUC diz respeito, a alteração processou-se no início dos anos 50. Foi então que, depois de efectuadas as devidas alterações tecnológicas, as caldeiras «Babcock \& Wilcox»começaram a queimar fuel-oil, em vez de carvão. Para isso contribuíram factores de carácter geral - vantagens comparativas, quanto aos respectivos custos - mas também factores específicos, de natureza local e regional

Localmente, havia que diminuir os efeitos poluidores da Central Térmica, contra os quais se insurgiam não só indivíduos - moradores nas imediações - - como entidades. Aliás, as reclamações terão surgido pouco depois da entrada em funcionamento da referida Central. De facto, como esta deve ter iniciado a laboração na segunda metade de 1944, já em 1946 se levantavam protestos contra a poluição por ela provocada. Tratava-se de «reclamações dos vizinhos da Central que eram incomodados pelos fumos saídos da chaminé, principalmente devido à elevada percentagem de anidrido sulfúrico, devido não só à qualidade do carvão utilizado - Cabo Mondego - como ainda por a central estar localizada na base duma colina e ter uma chaminé muito baixa» Além dos moradores da área abrangida, reclamaram igualmente contra os gases, oriundos da central Térmica, o Delegado de Saúde, a imprensa, a Junta da Província da Beira Litoral — em virtude de o Ninho dos Pequenitos estar a ser invadido por gases sulfurosos - e os próprios HUC $\left({ }^{65}\right)$.

A nível regional, um outro factor aconselhava que se efectuasse a referida transformação. Refiro-me à irregularidade, numa primeira fase e, posteriormente (Fevereiro de 1952), à suspensão do fornecimento de carvão pelo Cabo Mondego, em virtude «de a empresa produtora ter instalado ultimamente [estava-se em Maio de 1951] uma fábrica própria de cimento que consome grande parte do carvão extraído das suas minas» $\left({ }^{66}\right)$.

$\left({ }^{64}\right)$ A DGE/DS R C , Relatório de 1951.04.24.

${ }^{\left({ }^{6}\right)}$ ADGE / DSRC, ofício dirigido ao Secretário de Estado do Orçamento, em 1951.05.04. Ver, sobre os efeitos poluidores da combustão de carvão, a obra intitulada Steam Coal. Prospects to 2000, Paris, International Energy Agency / Organisation for Economic Co-Operation and Development, 1978, p. 87.

$\left({ }^{66}\right)$ ADGE / DSRC, ibidem. 


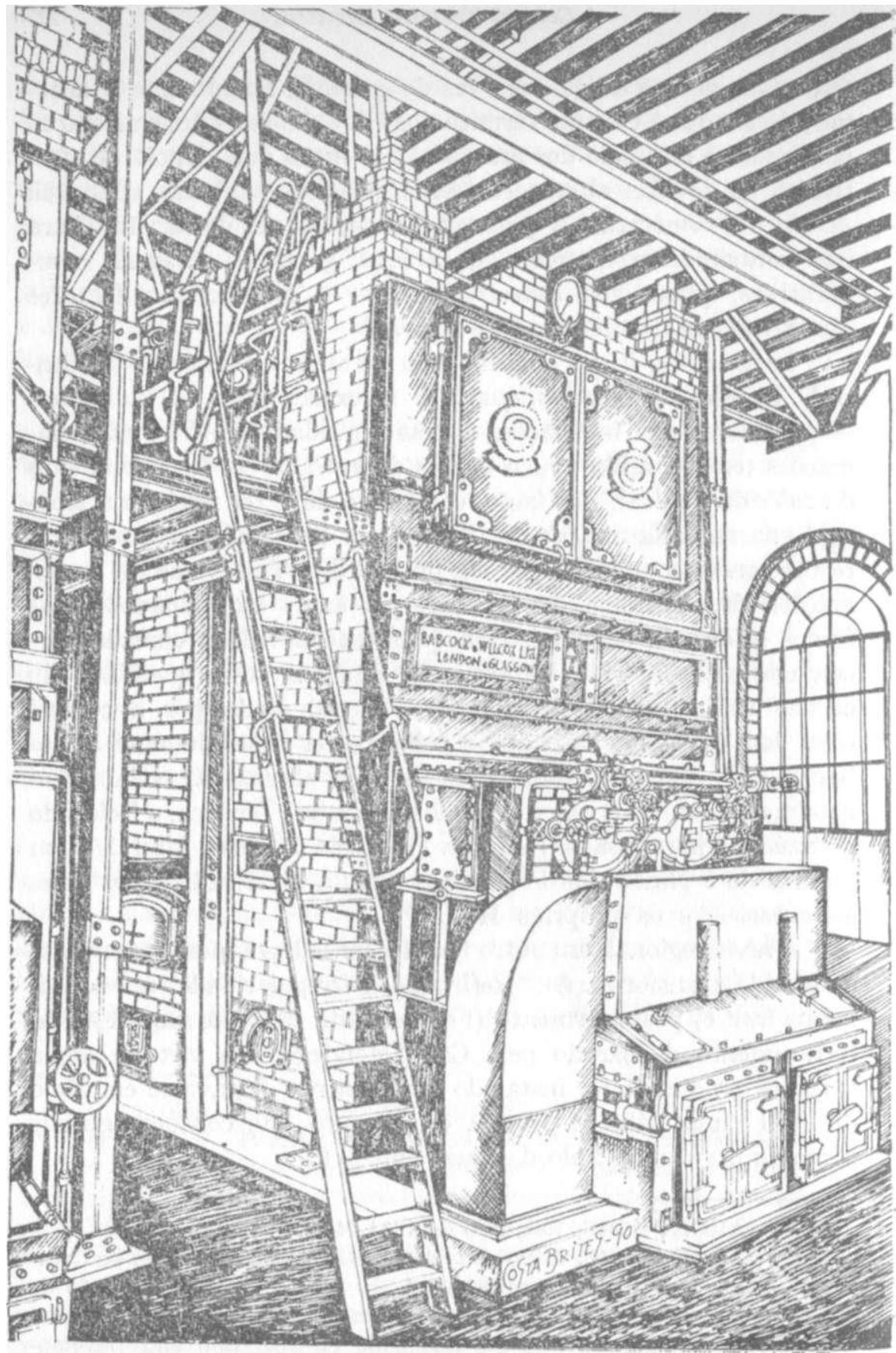

Fig. 8--Visão artística de Costa Brites, de uma das caldeiras, destacando-se a captação de materiais de natureza diversa (cerâmica, ferro e madeira) e a sua inserção no contexto das perspectivas visuais do edifício. 
Para que a Central Térmica pudesse utilizar fuel-oil, era necessário:

a) Adoptar queimadores com as características seguintes:

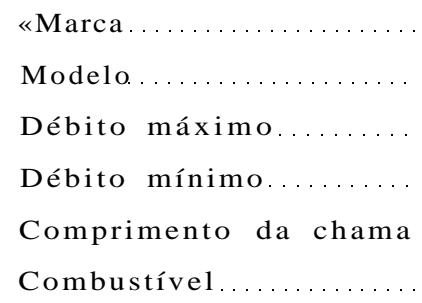

\author{
Pillard \\ D. C. R. \\ $100 \mathrm{Kg} / \mathrm{h}$ \\ $25 \mathrm{Kg} / \mathrm{h}$ \\ $1,5 \mathrm{~m}$ \\ Thick fuel-oil»
}

b) Efectuar, na Câmara de combustão, as seguintes transformações :
$\ll 1 .^{\circ}$ - Retirar a tremonha de carregamento, motor de grelha, etc. e imobilização da grelha.
$2 .^{\circ}$ - Isolamento da grelha com um pano de tijolo refractário nele existindo as aberturas para a entrada do ar secundário para a combustão. Apro- veitamento dos caixões da grelha para a distri- buição do ar e das condutas do mesmo.
$3 .^{\circ}$ - Corte e eliminação de uma parte da abóbada e estabelecimento dum muro no prolongamento da primeira divisória do circuito de gases.
$4 .^{\circ}$ - Substituição da chapa frontal inferior dos gera- dores para a adaptação dos queimadores.
$5 .^{\circ}$ - Eliminação da pequena abóbada de acendimento e prolongamento até à grelha da parede frontal do gerador.»

«Em virtude destas transformações o volume da câmara de combustão passa de 11 para $8,9 \mathrm{~m}^{3} \gg\left({ }^{67}\right)$.

Tornou-se ainda necessário construir três depósitos para fuel-oil (um no exterior da Central, de $50 \mathrm{~m}^{3}$ e dois no interior, de 2,5

$\left({ }^{67}\right)$ ADGE / DSRC, Processo n. ${ }^{\circ}$ 1517, ofício do Eng. ${ }^{\circ}$ Chefe da 4." Repartição dirigido ao Administrador dos HUC, em 1951.12.28. 
e $0,5 \mathrm{~m}^{3}$, respectivamente), bem como proceder a alterações na chaminé $\left({ }^{68}\right)$. Em Outubro de 1953, depois de efectuadas as respectivas provas (em 18 de Setembro e 19 de Outubro, do dito ano), a Central Térmica dos HUC já funcionava a fuel-oil ( $\left.{ }^{69}\right)$.

As vantagens da referida adaptação repercutiram-se a dois níveis: na salubridade, por ter sido drasticamente diminuído o grau de poluição até aí verificado na zona; na economia, pela diminuição nos custos que acarretou. A este propósito, sublinhava-se num requerimento da administração dos HUC: «A transformação requerida trará uma economia anual da ordem dos 200000\$00; libertará 5 operários que se empregam na britagem do carvão e podem destinar-se a outros serviços; libertará uma caminheta que se ocupa quási exclusivamente no transporte do carvão e seus resíduos». E acrescenta-se: «Evitará a deterioração do mobiliário e material metálico dos Hospitais, que está a ser fortemente atacado pelos gases sulfurosos» $\left({ }^{70}\right)$.

Mesmo considerando somente o factor económico, tratou-se de uma medida bastante eficaz. Com efeito, com um investimento de apenas $298450 \$ 00$ (custo das referidas adaptações para funcionamento a combustíveis líquidos), era possível economizar 17\$80 por tonelada de vapor produzido. A economia anual ascenderia assim, pelo menos, a $164985 \$ 72$, nas $9603,36 \mathrm{t}$ de vapor produzido pela Central (média de 800,28 t/mês) $\left(^{71}\right)$. Como se constata pelos números indicados, em menos de dois anos recuperar-se-ia o valor do investimento.

Para concluir este tópico, poder-se-á afirmar que a Central Térmica dos HUC cumpriu, efectivamente, a função para que foi instalada. Com efeito, o respectivo sistema - sem esquecer o seu «núcleo duro», constituído pelas gigantescas caldeiras B ABCOCK

${ }^{\left({ }^{68}\right)}$ ADGE / DSRC, idem, «Cópia da proposta para a empreitada de transformação e aplicação de queimadores de óleo às caldeiras da Central Térmica dos Hospitais da Universidade de Coimbra».

$\left({ }^{69}\right)$ A DGE/DSRC, auto de vistoria, datado de 1953.10.26.

$\left({ }^{\circ}\right)$ ADGE/DSRC, doc. de 1951.12.13.

(1) ADGE / DSRC, «Custo relativo da tonelada de vapor com [carvão do] Cabo Mondego e com óleo». 
\& WILCOX-permitiu que os Hospitais da Universidade de Coimbra dispusessem do indispensável vapor, nos seus múltiplos serviços, durante mais de quatro décadas (1944-1987). Devido à relativa flexibilidade da estrutura da Central Térmica e do respectivo equipamento, foi possível, numa segunda fase (1953-1987), passar a consumir combustíveis líquidos, eliminando assim, substancialmente, os inconvenientes do consumo do carvão (considerável acção poluidora, custos mais elevados e dificuldades no abastecimento).

4. SALVAGUARDA E REUTILIZAÇÃO DA CENTRAL TÉRMICA, COMO MONUMENTO INDUSTRIAL

Por tudo o que fica exposto, a ex-Central Térmica dos Hospitais da Universidade de Coimbra bem merece ser preservada, reutilizada e dada a conhecer. A respectiva construção, mais do que a monumentalidade de alguns edifícios então implantados na «Velha Alta», apresenta linhas simples e proporcionadas, conferindo-lhe as portas e janelas (altas e de caixilharia em ferro perfilado) uma certa elegância e razoável luminosidade. Da fase em que consumia carvão, o respectivo depósito (a sudeste, no extremo do edifício oposto à Rua P. António Vieira), bem como uma vagoneta, são testemunhos elucidativos. As velhas e gigantescas caldeiras - que, durante décadas, constituíram tecnologia da mais avançada - , ainda in loco, dão ao ambiente o aspecto característico de uma fábrica de vapor, de grande capacidade. A localização, ao fundo da colina, e a chaminé - de dimensões reduzidas, como vimos - permitem compreender o reverso da medalha: os malefícios da poluição, em especial enquanto funcionou a carvão. Em suma: trata-se não só de um «monumento»como também de um «sítio industrial».

Como é do conhecimento geral, a melhor forma de salvaguarda de um monumento industrial consiste, precisamente, na sua reutilização. Sob esta perspectiva, foi dado um passo importante, com a cedência do «Edifício das Caldeiras», pela Reitoria, ao Centro de Estudos de Fotografia da Associação Académica de Coimbra. As exposições que nele se têm efectuado, no âmbito dos Encontros 
de Fotografia $\left(^{72}\right)$, provam bem como se trata de um local muito adequado a este tipo de realizações culturais. Espera-se que, dentro em breve, se efectuem na ex-Central Térmica as adaptações anunciadas $\left({ }^{73}\right)$, para que seja possível intensificar a sua reutilização, dando-a a conhecer a um público mais vasto, constituído por nacionais e por estrangeiros.

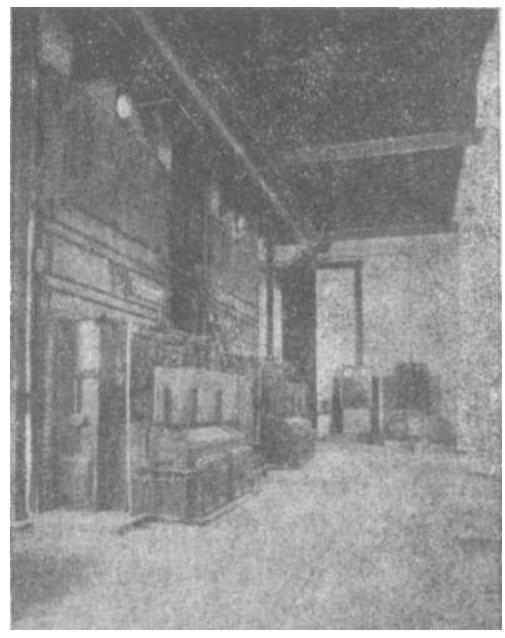

Fig. 9 - Galeria formada pela parede lateral (Nascente) do edifício e a parte anterior das caldeiras (fot. de Varela Pècurto).

$\left(^{72}\right)$ Por exemplo, nos $10 .{ }^{\circ *}$ Encontros de Fotografia (de 4 a 26 de Novembro de 1989), esteve patente, no Edifício das Caldeiras, uma exposição do célebre fotógrafo norte-americano, Joel-Peter Witkin.

$\left({ }^{73}\right)$ «A adaptação do local, preservando as instalações com interesse do ponto de vista da arqueologia industrial, dotará o CEF [Centro de Estudos de Fotografia] de um auditório, um sector pedagógico, uma biblioteca e ateliers para 'workshops', para além das zonas de exposições. É um projecto que se prevê vir a custar 15 mil contos e que resultará na criação de um grande centro de âmbito nacional dedicado à fotografia contemporânea» («A Fotografia nas Caldeiras», Expresso, de 1988.03.05). 
Uma outra hipótese - caso o referido Centro de Estudos não necessite de todo o espaço ou dele venha a prescindir — seria a de instalar no Edifício das Caldeiras um núcleo museológico - dos antigos HUC ou outro - , a exemplo do que se fez na-Estação Elevatória dos Barbadinhos (em Lisboa), hoje «Museu da Água Manuel da Maia», ao qual acaba de ser atribuído, pela UNESCO, o galardão de «Museu do Ano».

Em qualquer dos casos, o Edifício das Caldeiras e respectivo equipamento (ou seja a Central Térmica, embora desactivada) poderão transformar-se num pólo de atracção cultural e mesmo turístico, partindo do princípio (hoje geralmente aceite) de que o turismo muito se poderá valorizar com a introdução de novos valores culturais $(*)$.

JOSÉ M. AMADO MENDES

(*) Desejo manifestar o meu sincero reconhecimento ao amigo J. Costa Brites, pela prestimosa colaboração, ao fornecer-nos a sua visão artística (de rara sensibilidade e beleza) de uma das caldeiras, valorizando assim a perspectiva do referido monumento industrial (fig. 8). 